\title{
sciendo
}

\section{DIETARY SILAGE SUPPLEMENT MODIFIES FATTY ACID COMPOSITION AND BOAR TAINT IN PORK FAT}

\author{
Immaculada Argemí-Armengol ${ }^{1 *}$, Daniel Villalba ${ }^{1}$, Juan Ramón Bertolín² ${ }^{2}$ María Ángeles Latorre ${ }^{3}$, Núria Panella-Riera ${ }^{4}$, \\ Javier Álvarez-Rodríguez ${ }^{1}$
}

\author{
'Department of Animal Science, University of Lleida, Av. Rovira Roure 191, 25198 Lleida, Spain \\ ${ }^{2}$ Agrifood Research and Technology Centre of Aragón, Avda. Montañana 930, 50059 Zaragoza, Spain \\ ${ }^{3}$ Faculty of Veterinary Medicine, University of Zaragoza, C. Miguel Servet 177, 50013 Zaragoza, Spain \\ ${ }^{4}$ Institute of Agrifood Research and Technology, Finca Camps i Armet, 17121 Monells, Spain \\ •Corresponding author: immaculada.argemi@udl.cat
}

\begin{abstract}
In organic pig husbandry, the use of roughage is mandatory as dietary supplement. This study investigated the effects of oat silage on the fatty acid composition, in entire males and gilts, as well as indole and skatole levels in perirenal adipose tissue of entire males. Entire males and gilts (forty-five to forty-eight pigs/sex) were assigned to two dietary roughage feeds (control with straw vs. oat silage). There was no significant effect of silage or sex on total SFA and MUFA in pork fat. However, the oat silage increased the total PUFA $n-3$ and decreased the PUFA $n-6 / n-3$ ratio. The content of boar taint compounds (skatole and indole) in the entire male pigs did not differ between diets, although human nose scoring rejected in a greater extent more pork fat from entire males supplemented with oat silage, compared with those only supplied with straw. Approximately $50 \%$ of the entire males (90 to $97 \mathrm{~kg}$ of carcass) had low skatole values $(\leq 0.1 \mu \mathrm{g} / \mathrm{g})$, that were below the range of boar taint detection, regardless of the feeding regime. This finding indicates that more studies should be performed to avoid the problem of taint detection in entire males under organic production.
\end{abstract}

Key words: entire male, fatty acids, omega-3, indole, skatole

The World Health Organization (WHO) recommends limiting the amount of consumed fat and a healthier fatty acid composition of meat, with a higher proportion of polyunsaturated fatty acids (PUFA) to saturated fatty acids (SFA) and a more favourable balance between PUFA n-6 and n-3 (Wood et al., 2004). The contents of PUFA in food, e.g., linoleic acid (C18:2 n-6), $\alpha$-linolenic acid (C18:3 n-3), gain attention by consumers because of their increased awareness concerning health and nutrition (Hathwar et al., 2012). The body fatty acids profile from monogastric animals generally represents a higher $n-6 / n-3$ ratio compared to those of ruminants as they are mainly fed with high concentrate grain diets, rich in linoleic acid (Raes et al., 2004). Total PUFA n-3 (mainly C18:3 n-3) may be increased through grass feeding in free-range (for example, in Iberian pigs) and as a result of exercise (Rey et al., 2006), as well as using dietary vegetable oils (organic production) compared to animal fat sources (conventional production) (Álvarez-Rodríguez et al., 2016).

The use of dietary roughage is not common in pig production, but it is mandatory in organic husbandry and normally accomplished through low quality straw provided as bedding. According to Wallenbeck et al. (2014), roughage can provide some nutrients to growing-finishing pigs, but little is known about its fatty acid accretion in organic husbandry, which implies dietary roughage inclusion and management practice differences, compared to conventional pig production. Taking into account that the internal fat depots had the highest amount of n-3 fatty acids (Daza et al., 2017), perirenal fat may be used as a proxy to evaluate the impact of feeding strategies on fatty acid quality.

Also, there is an increasing demand for more welfare friendly alternatives to surgical castration of male pigs, especially under organic conditions (Thomsen et al., 2012). Male castration is largely used to avoid boar taint, a very unpleasant odour and flavour caused by the accumulation of two naturally occurring chemical compounds (skatole and androstenone) in the fat tissue of uncastrated males (Bonneau et al., 2000). One compound associated with this offensive odour is the steroid androstenone ( $5 \alpha$-androst-16-en-3-one), which is synthesised in the testes of boars, released into the blood. Likewise, skatole (3-methyl indole) is a product of the degradation of tryptophan exhibiting a faecal-like odour which is produced in the intestine by bacteria (Bonneau et al., 2000). Both substances are decomposed in the liver, and the fraction that is not metabolised in the liver, as a lipophilic substance, is accumulated in adipose tissue, causing boar taint. 
In countries like The Netherlands and Germany, to avoid the risk of selling boar tainted meat to the consumers, boar taint detection must be performed on all entire male carcasses, and this is performed by using a human nose methodology in which a person smells a heated sample of fat from each entire male carcass and classifies it into acceptable/not acceptable (Aaslyng et al., 2019). Boar taint prevalence can be influenced by slaughter weight, genetic background and nutritional and environmental factors (Zamaratskaia and Squires, 2009)

Thus, there are controversial results to be applicable to the future production of entire male pigs within the organic pig production system. The presence of skatole in the fat tissue is related to the potential of pigs to metabolise it and also related to nutritional factors, since it has been hypothesized that the inclusion of fibre-rich feedstuffs in diet, as cereal straw and especially silage (mainly containing non-starch polysaccharides) may reduce the backfat skatole levels by affecting its rate of clearance (Hansen et al., 2008).

So far, only few studies have been conducted on the quality of pork fat produced under organic conditions. Therefore, the aim of the present study was to evaluate the effects of dietary oat silage supplement and sex on fatty acid profile of perirenal adipose tissue as a carcass lipid proxy. In addition, in entire males, the effect of dietary oat silage supplement on indole and skatole content in perirenal adipose tissue and human nose scoring for boar taint compounds was also assessed.

Our hypothesis was that improving the quality of dietary fibre supplementation in organic pig diet would boost the quality of the accreted body fatty acids and may reduce the concentration of skatole boar taint compounds in males.

\section{Material and methods}

\section{Animals, experimental design and treatments}

A total of ninety-three growing-finishing pigs (forty-five were females and forty-eight were entire males) with an average body weight (BW) of $51.8 \mathrm{~kg}$ (standard deviation, $\mathrm{SD}=7.6 \mathrm{~kg}$ ) were individually ear tagged and included in this experiment, which was carried out in a commercial organic pig farm in northwest Catalonia ("Granja Casat", Sarroca de Bellera, Lleida, Spain; $1,030 \mathrm{~m}$ above sea level). The experiment was conducted between June and September 2019 (total duration 87 days). The average monthly temperature for June, July, August and September was $17.1,19.7,19.2$ and $16.7^{\circ} \mathrm{C}$, respectively; however, the outside maximum temperature reached $30^{\circ} \mathrm{C}$, especially in June (25th-30th) and July (22nd-25th). The pigs were reared in accordance with the European Community standards for organic livestock (space allowance $\geq 1.3 \mathrm{~m}^{2} /$ pig indoor plus 1.0 $\mathrm{m}^{2} /$ pig outdoor) and livestock products (EC Regulation 889/2008 supplementing the EC Regulation 834/2007). The indoor area was cereal straw bedded pens with con- crete floor and a longitudinal trough with roughage. The outdoor area was a loose-house shed with concrete floor pens without bedding and $20 \%$ slatted floor below the feeding and drinking area. Each pen had two dry singlespace self-feeders and two square nipple drinkers in the outdoor area. The barn was naturally ventilated.

The experimental design was factorial, with two feeding strategies (grain plus straw vs. grain plus oat silage) and sex (females or entire males). The pigs belonged to two consecutive 3 -week interval batches and they were the progeny of crossbred sows, Large White $\times$ Landrace (CG36 Naïma) and Duroc boars (UPB Genetic World, Navàs, Spain). The pigs were allocated into two treatments (46-47 pigs/treatment) and housed in four groups of 22-24 pigs, balanced by sex (45-47 pigs/sex) and initial BW per treatment. Entire males were kept in separate pens from gilts. They were housed to meet both the organic husbandry housing requirements and animal behaviour interactions, that were promoted in this production system, and allowed us to study the dietary supplementation response and boar taint accretion (sharing pen feeders and drinkers, lying area with straw bed, fouling and locomotion area). Even though the productive results of the animals within a pen may be partly correlated, the individual fatty acid and boar taint compounds of each animal were considered because the longitudinal troughs allowed an individual control of the supplementary roughage intake. Each pen had a supplementary forage trough in the indoor area. It was filled daily, with $200 \mathrm{~g}$ dry matter (DM)/pig/day of winter cereal straw (wheat and barley) in control treatment or with the same amount of chopped oat silage (whole-crop cut at the soft dough stage) supplement (5-cm length approximately, $\mathrm{pH}=5.6 \pm 0.07)$, until the target slaughter weight (120 kg of BW, approximately). All the pigs were fed ad libitum with the same commercial organic pelleted feed, whose ingredients were barley grain $(39 \%)$, oat (10\%), wheat $(30 \%)$, expeller soybean meal $(17 \%)$, sunflower oil $(1.53 \%)$, minerals $(1.85 \%)$ and vitamin-micromineral premix $(0.5 \%)$, and received straw bales as bedding material $(0.5 \mathrm{~kg} \mathrm{DM} /$ day/pig) at weekly intervals, which also served as ad libitum dietary roughage source. The proximate chemical composition of the pelleted compound feed and roughages was carried out according the methods of AOAC (2000). The feed composition met the nutritional recommendations proposed by the ITAB (2014) for organic pigs. Briefly, the concentrate provided $13.5 \%$ of crude protein, $0.78 \%$ of total lysine and $5.9 \%$ of ether extract. The estimated digestible energy (DE) content of the concentrate, based on proximate chemical composition using EvaPig ${ }^{\circledR}$ (INRA, 2008), was 14.4 MJ $\mathrm{DE} / \mathrm{kg}$ of feed. The cereal straw and oat silage provided $3.0 \%$ and $8.1 \%$ of crude protein and $83.4 \%$ and $71.9 \%$ of neutral-detergent fibre, respectively.

\section{Abattoir sampling}

When their body weight was around $120 \mathrm{~kg} \mathrm{BW}$, the pigs were transported to a commercial abattoir $(185 \mathrm{~km}$ 
away) (Escorxador Comarcal del Moianès, S.A., Moià, Spain) in two batches. Pigs were brought in the morning (between 11:00 and 12:00) with a small truck provided with a relatively flat loading ramp. At the abattoir, animals were allowed 3-4 hours to rest with full access to water but not to feed. Pigs were stunned by $\mathrm{CO}_{2}$ using a dip lift system, exsanguinated, scalded, skinned, eviscerated according to standard commercial procedures and split down the midline. Hot carcass weight was individually recorded after splitting to calculate the dressing out proportion. A sub-sample of 56 carcasses (control, $\mathrm{n}=23$ and silage, $\mathrm{n}=33$ ), from two sexes (entire males, $\mathrm{n}=36$ and gilts, $\mathrm{n}=20$ ), was weighed (including the head and tail) and perirenal adipose tissue was sampled (100 g approximately) within 30 minutes post-mortem. The slaughter batches were balanced according to the treatments and sexes. The samples were stored in ice until arrival to laboratory and therefore they were packaged in vacuum-opaque bags and ultra-frozen at a temperature of $-80^{\circ} \mathrm{C}$ until fatty acid composition and boar taint compound analyses.

Analysis of fatty acid composition in feedstuffs and perirenal adipose tissue

The fatty acid composition of feeds and perirenal adipose tissue were analysed according to Sukhija et al. (1988) and Yagoubi et al. (2018), respectively. Briefly, $500 \mathrm{mg}$ of feed samples and $100 \mathrm{mg}$ of perirenal adipose tissue samples were minced and mixed with $3 \mathrm{~mL}$ of heptane and $4 \mathrm{~mL}$ of $\mathrm{NaOH} / \mathrm{CH}_{3} \mathrm{OH} 0.5 \mathrm{M}$. The mixture was homogenized with vortex and heated with agitation for $20 \mathrm{~min}$ at $70^{\circ} \mathrm{C}$ for feeds and for $20 \mathrm{~min}$ at $50^{\circ} \mathrm{C}$ for perirenal adipose tissue samples, followed by cooling for 6-7 min. Then $4 \mathrm{~mL}$ of acetyl chloride/ $\mathrm{CH}_{3} \mathrm{OH}(1 / 10 \mathrm{v} / \mathrm{v})$ was added. The mixture was shacked and reheated for $60 \mathrm{~min}$ at $50^{\circ} \mathrm{C}$ and $70^{\circ} \mathrm{C}$ respectively. After cooling to ambient temperature, $2 \mathrm{~mL}$ of water milli-Q was added. Then the mixture was shacked, homogenized and centrifuged for $5 \mathrm{~min}, 3500 \mathrm{rpm}$ at $10^{\circ} \mathrm{C}$. The upper layer (heptane) was collected and transferred to $5 \mathrm{ml}$ tubes with anhydrous $\mathrm{Na}_{2} \mathrm{SO}_{4}$ to remove traces of water and in the case of feeds also with activated carbon to remove interfering compounds like pigments. The mixture was shaken during 10 minutes and then centrifuged for $5 \mathrm{~min}$, $3500 \mathrm{rpm}$ at $10^{\circ} \mathrm{C}$. One $\mathrm{ml}$ of the supernatant was carefully transferred into an amber screw cap glass vial for gas chromatography. Fatty acids were analysed using a Bruker 436-GC gas chromatograph equipped with an autosampler CP-8400 (Bruker, Billerica, USA), highly polar biscyanopropyl capillary column (SP-2560, $100 \mathrm{~m}$ $\times 0.25 \mathrm{~mm}$ D.I $\times 0.20 \mu \mathrm{m}$, Supelco, Saint Louis, USA), flame ionization detector and Compass CDS software. Helium flux was $1.5 \mathrm{~mL} / \mathrm{min}$ and the oven program temperature was $90^{\circ} \mathrm{C}$ for $5 \mathrm{~min}$, then $15^{\circ} \mathrm{C} / \mathrm{min}$ to $165^{\circ} \mathrm{C}$ maintained for 44 minutes and finally $50^{\circ} \mathrm{C} / \mathrm{min}$ to $220^{\circ} \mathrm{C}$ maintained for 24.9 minutes with a total time chromatogram analysis of $80 \mathrm{~min}$. One $\mu \mathrm{L}$ of samples with $1 / 50$ split were injected and the injector and detector tempera- tures were maintained at $250^{\circ} \mathrm{C}$. The fatty acids identification was based on retention times as compared with those of the standard fatty acid methyl esters (FAMEs) mixtures: GLC-532, GLC-401, GLC-463 and GLC-538 (Nu-Check Prep, Elysian, USA) while the quantification was carried out following the procedures described in UNE-EN ISO 12966-4.

Iodine value (IV), a measure of fat quality, with a greater number indicating a greater concentration of unsaturated fatty acids and thus softer fat, was calculated according to AOCS (1998) equation: (C16:1*0.95) + $(\mathrm{C} 18: 1 * 0.86)+(\mathrm{C} 18: 2 * 1.732)+(\mathrm{C} 18: 3 * 2.616)$.

\section{Chemical analysis of skatole and indole and hu- man nose scoring}

Thirty-six entire male pigs belonging to the first and second slaughtered batches were used to evaluate selected boar taint compounds (skatole and indole) in adipose tissue (control $n=19$ and silage $n=17$ ) by high-performance liquid chromatography (HPLC), according to García-Regueiro and Rius (1998), and their levels were expressed as $\mu \mathrm{g} / \mathrm{g}$ adipose tissue. The results were classified according to the skatole level (Bonneau and Chevillon, 2012), as follows: low $\leq 0.1 \mu \mathrm{g} / \mathrm{g}$, medium $0.11-0.20$ $\mu \mathrm{g} / \mathrm{g}$, high $>0.20 \mu \mathrm{g} / \mathrm{g}$ of adipose tissue. In accordance with this classification, the pork fat obtained from carcasses with a high or medium and high concentration of skatole can be considered to be an issue for some consumers, whilst low levels may be accepted (Font i Furnols et al., 2003). Samples were scored for 'presence or absence of boar taint' by human nose methodology (Mathur et al., 2012) by one trained independent panellist and blind to the origin of the fat sample. Human nose scoring was selected as sensory proof of key boar taint compounds in pork fat, including androstenone and skatole. On the day of scoring, the fat samples were thawed and heated by a hot soldering iron that was first heated to a temperature of $370^{\circ} \mathrm{C}$. The hot iron tip, about $6 \mathrm{~mm}$ wide and $20 \mathrm{~mm}$ long, was applied to the sample for about 2-3 s.

\section{Statistical analysis}

The data were analysed with the JMP Pro 14 statistical software (SAS Institute, Cary, NC, USA). Carcass weight and fatty acid composition were analysed with a standard model including dietary treatment, sex, slaughter batch and their single interactions as fixed effects. Single interactions are not reported in the text as they were non-significant $(\mathrm{P}>0.05)$. The skatole and indole levels in perirenal adipose tissue of entire males were analysed through standard least square models that included the dietary treatment and slaughter date as fixed effects. Carcass weight was initially considered as a covariate in the models, but it was removed because it was non-significant $(\mathrm{P}>0.05)$. Values are presented as least square means \pm standard error of the mean. The level of significance was set at 0.05 , but tendencies were commented if the level of significance was below 0.10. Differences between least square means were assessed with 
the Tukey test. The associations between feeding treatment and medium-high or high skatole concentration samples, as well as between feeding treatment and human nose scoring was assessed with contingency tables with Pearson tests. Finally, the association between the skatole level and the human nose panellist scoring was also evaluated.

\section{Results}

\section{Fatty acids profile in feedstuffs}

No leftovers of the oat silage supplement were recorded throughout the study (all was eaten), whereas the winter cereal straw was offered ad libitum either as a supplement in the trough and as bedding in control treatment or just as bedding in silage treatment.

The descriptive fatty acids profile in the dietary feedstuffs in this study is summarized in Table 1. The current gas chromatography procedure detected eight to eleven fatty acids. The main fatty acids in concentrate feed were (in decreasing order of importance) C18:2 n-6 (linoleic), C18:1 cis-9 (oleic) and C16:0 (palmitic); in the winter cereal straw they were $\mathrm{C} 16: 0$ (palmitic), $\mathrm{C} 18: 0$ (stearic) and C18:2 n-6 (LA, linoleic); and in oat silage they were C18:2 n-6 (linoleic), C16:0 (palmitic) and C18:1 cis-9 (oleic). Compared with winter cereal straw, concentrate and oat silage had higher content of PUFA than MUFA and SFA.

\section{Carcass weight}

The carcass weight was not affected by feeding regime $(100.1 \pm 2.73 \mathrm{~kg}$ vs. $97.0 \pm 1.39 \mathrm{~kg}$, in control and silage treatment, $\mathrm{P}>0.10)$ but it was lower in entire males than in gilts $(94.2 \pm 1.31 \mathrm{~kg}$ vs. $102.9 \pm 2.67 \mathrm{~kg}$, $\mathrm{P}<0.01)$. Carcass weight of entire males did not differ between both feeding strategies $(98.0 \pm 1.80 \mathrm{~kg}$ vs. $90.5 \pm 1.90 \mathrm{~kg}$ in control and silage, respectively, $\mathrm{P}>0.10)$.

\section{Fatty acids profile in perirenal adipose tissue}

Effect of dietary silage supplement

The dietary silage supplement did not affect the composition of any individual SFA in perirenal pork fat, while it only reduced the C18:1 cis 11 MUFA content (Table $2, \mathrm{P}<0.01)$. In contrast, the sum of minor PUFA $n-6$ $(\mathrm{C} 18: 3 n-6+\mathrm{C} 20: 2 n-6+\mathrm{C} 20: 4 n-6+\mathrm{C} 22: 4 n-6+\mathrm{C} 22: 5$ $n-6)$, and minor PUFA $n-3$ (C18:3 n-3, C20:5 n-3 eicosapentaenoic acid-EPA, and C22:6n-3 docosahexaenoic acid-DHA) were increased by supplying the dietary silage supplement $(\mathrm{P}<0.05)$. Thereby, the overall sum of $n$-3 PUFA was lower in control than in silage treatment (Table 3, $\mathrm{P}<0.001$ ). The sum of MUFA tended to be greater in control than in silage treatment (Table 3, $\mathrm{P}=0.08$ ) and accordingly, the MUFA/SFA ratio was higher in the former than in the latter group $(\mathrm{P}<0.05$, Table 3).

Table 1. Fatty acid composition of feeds ( $\mathrm{g} / 100 \mathrm{~g}$ of fatty acid methyl esters, means)

\begin{tabular}{|c|c|c|c|}
\hline Fatty acid & Concentrate $^{1}$ & Winter cereal straw & Oat silage \\
\hline C12:0, lauric & n.d. ${ }^{2}$ & 1.2 & 0.2 \\
\hline C14:0, myristic & 0.2 & 5.1 & 0.5 \\
\hline C15:0, pentadecylic & n.d. & 0.4 & 0.1 \\
\hline C16:0, palmitic & 16.0 & 48.7 & 23.8 \\
\hline C18:0, stearic & 7.2 & 28.5 & 10.6 \\
\hline C20:0, arachidic & n.d. & 0.2 & n.d. \\
\hline Total SFA ${ }^{3}$ & 23.5 & 84.1 & 35.3 \\
\hline C16:1 cis-9, palmitoleic & 0.1 & 0.2 & 0.2 \\
\hline C18:1 cis-9, oleic & 19.8 & 3.2 & 14.8 \\
\hline C18:1 cis-11, cis-vaccenic & 1.6 & 0.5 & 1.4 \\
\hline Total MUFA ${ }^{3}$ & 21.6 & 3.9 & 16.4 \\
\hline C18:2n-6 $6^{4}$, LA, linoleic & 52.3 & 7.7 & 40.8 \\
\hline C18:3n-35, ALA, $\alpha$-linolenic & 2.6 & 4.4 & 7.4 \\
\hline Total PUFA $n-6$ & 52.3 & 7.7 & 40.8 \\
\hline Total PUFA $n-3$ & 2.6 & 4.4 & 7.4 \\
\hline Total PUFA ${ }^{3}$ & 54.9 & 12.0 & 48.2 \\
\hline PUFA $n-6 /$ PUFA $n-3$ ratio & 20.4 & 1.8 & 5.5 \\
\hline
\end{tabular}

${ }^{1}$ The proximal composition of feeds is shown elsewhere (Argemí-Armengol et al., 2020). Briefly, the crude protein of concentrate was $13.5 \%$, while in winter cereal straw it was 3.0\% and in oat silage it was $8.1 \%$. The crude fibre of concentrate was $4.6 \%$ while in winter cereal straw it was $53.2 \%$ and in oat silage it was $40.9 \%$.

${ }^{2}$ n.d: not detected

${ }^{3}$ SFA: saturated fatty acids, MUFA: monounsaturated fatty acids, PUFA: polyunsaturated fatty acids.

${ }^{4} n-6$ : omega- 6 fatty acids.

${ }^{5} n-3$ : omega- 3 fatty acids. 
Table 2. Effect of feeding regime and sex on fatty acid profile ( $\mathrm{g} / 100 \mathrm{~g}$ perirenal fat)

\begin{tabular}{|c|c|c|c|c|c|c|c|}
\hline \multirow{2}{*}{ Item } & \multicolumn{2}{|c|}{ Feeding regime } & \multicolumn{2}{|c|}{ Sex } & \multirow{2}{*}{ SEM } & \multicolumn{2}{|c|}{$\mathrm{P}^{2}$} \\
\hline & control & oat silage & entire males & gilts & & $\mathrm{F}^{3}$ & $\mathrm{~S}^{4}$ \\
\hline $\mathrm{n}$ & 23 & 33 & 36 & 20 & & & \\
\hline \multicolumn{8}{|l|}{ SFA } \\
\hline Minor $^{1}$ SFA & 0.23 & 0.24 & 0.22 & 0.25 & 0.006 & 0.85 & $<0.01$ \\
\hline C14:0, myristic & 1.62 & 1.64 & 1.55 & 1.71 & 0.036 & 0.76 & $<0.01$ \\
\hline C15:0, pentadecylic & 0.06 & 0.05 & 0.06 & 0.06 & 0.004 & 0.06 & 0.45 \\
\hline C16:0, palmitic & 27.92 & 28.17 & 27.44 & 28.65 & 0.296 & 0.60 & $<0.01$ \\
\hline $\mathrm{C} 17: 0$ & 0.16 & 0.15 & 0.16 & 0.15 & 0.012 & 0.64 & 0.66 \\
\hline C18:0, stearic & 13.97 & 14.92 & 14.31 & 14.58 & 0.397 & 0.13 & 0.64 \\
\hline C20:0, arachidic & 0.01 & 0.02 & 0.02 & 0.01 & 0.006 & 0.56 & 0.44 \\
\hline \multicolumn{8}{|l|}{ MUFA } \\
\hline Minor $^{1}$ MUFA & 0.04 & 0.03 & 0.03 & 0.04 & 0.002 & 0.69 & $<0.05$ \\
\hline C16:1 cis-7, hexadecenoic & 0.25 & 0.22 & 0.23 & 0.23 & 0.01 & 0.1 & 0.83 \\
\hline C16:1 cis-9, palmitoleic & 1.31 & 1.17 & 1.16 & 1.33 & 0.064 & 0.16 & 0.08 \\
\hline C16:1 cis-11, palmitovaccenic & 0.11 & 0.09 & 0.10 & 0.10 & 0.006 & 0.18 & 0.73 \\
\hline C17:1 cis-9, margarinic & 0.12 & 0.10 & 0.10 & 0.11 & 0.008 & 0.18 & 0.46 \\
\hline C18:1 cis-9, oleic & 26.30 & 26.99 & 26.53 & 26.75 & 0.42 & 0.3 & 0.73 \\
\hline C18:1 cis-11, cis-vaccenic & 5.24 & 4.65 & 4.79 & 5.10 & 0.16 & $<0.05$ & 0.18 \\
\hline \multicolumn{8}{|l|}{ PUFA } \\
\hline Minor $^{1}$ PUFA $n-6$ & 0.04 & 0.06 & 0.05 & 0.04 & 0.004 & $<0.001$ & 0.11 \\
\hline C18:2 n-6, linoleic & 21.29 & 21.21 & 22.39 & 20.10 & 0.759 & 0.94 & $<0.05$ \\
\hline C18:3 n-3, $\alpha$-linolenic & 0.54 & 0.72 & 0.60 & 0.65 & 0.025 & $<0.001$ & 0.12 \\
\hline C20:3 n-6, homo- $\gamma$-linolenic acid & 0.04 & 0.11 & 0.09 & 0.06 & 0.011 & $<0.001$ & 0.07 \\
\hline C20:5 n-3, eicosapentaenoic (EPA) & 0.06 & 0.13 & 0.09 & 0.10 & 0.010 & $<0.001$ & 0.75 \\
\hline C22:5 n-3, docosapentaenoic & 0.01 & 0.01 & 0.01 & 0.01 & 0.002 & 0.56 & 0.14 \\
\hline C22:6n-3, docosahexaenoic (DHA) & n.d & 0.01 & 0.01 & 0.01 & 0.001 & $<0.01$ & 0.94 \\
\hline
\end{tabular}

${ }^{1}$ Minor SFA $=\Sigma \mathrm{C} 8: 0+\mathrm{C} 9: 0+\mathrm{C} 10: 0+\mathrm{C} 11: 0+\mathrm{C} 12: 0$, Minor MUFA $=\Sigma \mathrm{C} 10: 1+\mathrm{C} 12: 1$ cis9+ C14:1. Minor PUFA $n-6=\mathrm{C} 18: 3 n-6+\mathrm{C} 20: 2 n-6+\mathrm{C} 20: 4 n-6$ $+\mathrm{C} 22: 4$ n-6 + C22:5 n-6.

${ }^{2} \mathrm{P}$ : Statistical significance.

${ }^{3} \mathrm{~F}$ : Feeding regime.

${ }^{4} \mathrm{~S}$ : Sex.

The interaction between $\mathrm{F}$ and $\mathrm{S}$ was not significant $(\mathrm{P}>0.05)$.

Table 3. Effect of feeding regime and sex on fatty acid groups $(\mathrm{g} / 100 \mathrm{~g}$ perirenal fat $)$, ratios and related indices

\begin{tabular}{|c|c|c|c|c|c|c|c|}
\hline \multirow{2}{*}{ Item } & \multicolumn{2}{|c|}{ Feeding regime } & \multicolumn{2}{|c|}{ Sex } & \multirow{2}{*}{ SEM } & \multicolumn{2}{|c|}{$\mathrm{P}^{7}$} \\
\hline & control & oat silage & entire males & gilts & & $\mathrm{F}^{8}$ & $\mathrm{~S}^{9}$ \\
\hline $\mathrm{SFA}^{1}$ & 43.98 & 45.19 & 43.75 & 45.41 & 0.59 & 0.20 & 0.06 \\
\hline MUFA $^{2}$ & 34.04 & 32.57 & 32.95 & 33.66 & 0.54 & 0.08 & 0.37 \\
\hline PUFA $^{3}$ & 21.98 & 22.24 & 23.30 & 20.93 & 0.79 & 0.83 & $<0.05$ \\
\hline$\sum n-6^{4}$ & 21.37 & 21.38 & 22.54 & 20.21 & 0.76 & 0.99 & $<0.05$ \\
\hline$\sum n-3^{5}$ & 0.61 & 0.87 & 0.76 & 0.72 & 0.03 & $<0.001$ & 0.32 \\
\hline$n-6 / n-3$ & 35.69 & 25.07 & 31.3 & 29.46 & 1.05 & $<0.001$ & 0.23 \\
\hline PUFA/SFA & 0.51 & 0.50 & 0.54 & 0.47 & 0.03 & 0.76 & $<0.05$ \\
\hline MUFA/SFA & 0.78 & 0.72 & 0.76 & 0.74 & 0.01 & $<0.05$ & 0.59 \\
\hline Calculated IV ${ }^{6}$ & 67.50 & 66.57 & 68.79 & 65.28 & 0.04 & 0.59 & $<0.05$ \\
\hline
\end{tabular}

${ }^{1}$ SFA: sum of saturated fatty acid.

${ }^{2}$ MUFA: sum of monounsaturated fatty acid.

${ }^{3}$ PUFA: sum of polyunsaturated fatty acid.

${ }^{4} n-6$ : omega- 6 fatty acids.

${ }^{5} n-3$ : omega-3 fatty acids.

${ }^{6} \mathrm{IV}$ : iodine value.

${ }^{7} \mathrm{P}$ : Statistical significance.

${ }^{8} \mathrm{~F}$ : Feeding regime.

${ }^{9} \mathrm{~S}$ : Sex.

The interaction between $\mathrm{F}$ and $\mathrm{S}$ was not significant $(\mathrm{P}>0.05)$. 


\section{Effect of sex}

Entire males showed lower individual SFA content (C8:0 to $\mathrm{C} 12: 0, \mathrm{C} 14: 0$ and $\mathrm{C} 16: 0)$ than gilts (Table 2, $\mathrm{P}<0.01$ ). However, the individual MUFAs were slightly affected by sex, as only the minor short chain MUFA (C10:1 to $\mathrm{C} 14: 1)$ were lower in entire males than in gilts $(\mathrm{P}<0.05)$, whereas the major PUFA $n-6(\mathrm{C} 18: 2 n-6)$ was greater in entire males than in gilts $(\mathrm{P}<0.05)$. Overall, the entire males had greater total PUFA, mainly $n-6$ content, and iodine value (IV) in their fat compared to gilts (Table 3, $\mathrm{P}<0.05$ ), which lead to greater PUFA/SFA ratio in entire male compared to their gilt counterparts $(\mathrm{P}<0.05)$.

Boar taint in perirenal adipose tissue of entire males

The effects of dietary roughage supplement on the studied compounds related to boar taint in the perirenal adipose tissue from entire males are shown in Figure 1. Skatole and indole concentrations in perirenal fat did not differ significantly between feeding strategies $(\mathrm{P}>0.05)$.
The results regarding the association between feeding regime and pork fat rejection due to boar taint based on the skatole level thresholds and the human nose rejection are shown in Figure 2. There was no difference between feeding strategies in the proportion of pork fat samples with medium and high skatole values $(\mathrm{P}>0.05)$. Considering only the high level of skatole with respect to the rest, there was no difference in the pork fat rejection between the two treatments ( 21.1 vs. $29.4 \%$ in control and silage, respectively, $\mathrm{P}=0.56$ ). However, the dietary silage supplement resulted in a greater proportion of rejected pork fat based on human nose scoring $(\mathrm{P}<0.05)$.

There was a high degree of association between the skatole level and the human nose panellist scoring, while $75.0 \%$ of the high skatole fat samples and $66.7 \%$ of the medium-high skatole fat samples were scored for boar taint; no sample with low skatole level was scored for boar taint $(\mathrm{P}<0.001)$.
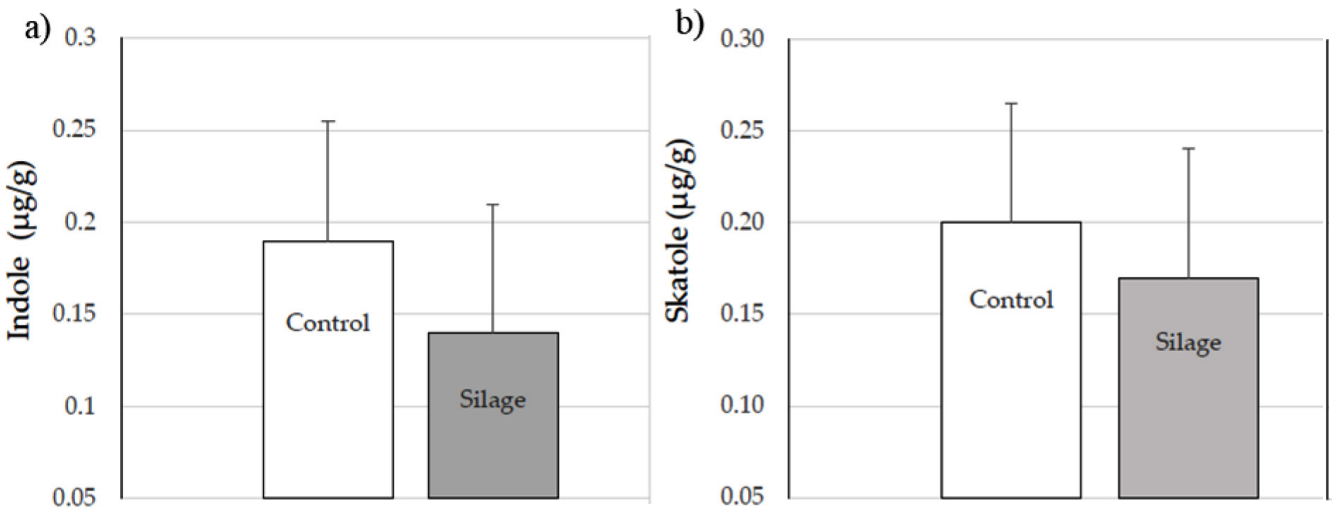

Figure 1. Effect of feeding regime (control vs. silage) on indole level $(\mu \mathrm{g} / \mathrm{g})(\mathrm{a})$ and skatole level $(\mu \mathrm{g} / \mathrm{g})(\mathrm{b})$ in perirenal fat of male pigs (least square means \pm standard error of the mean)

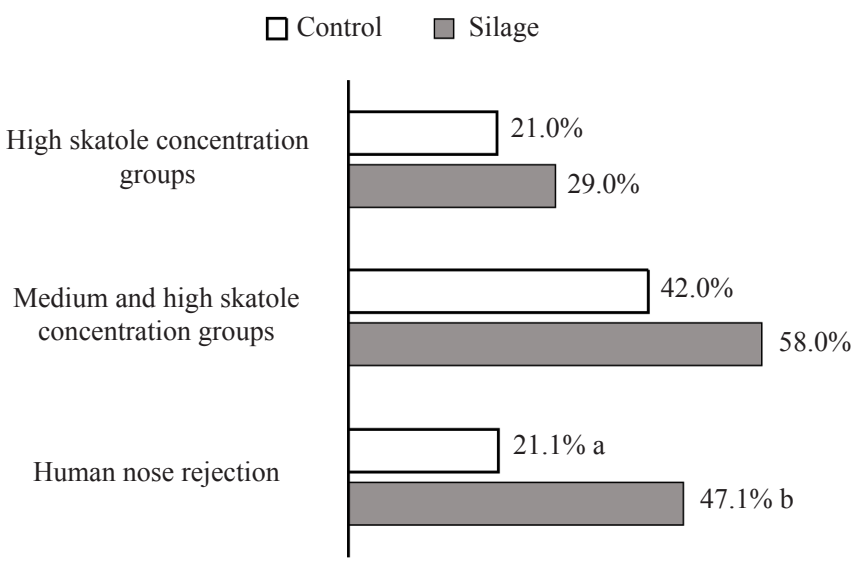

Figure 2. Association between feeding regime (control vs. silage) and pork fat rejection due to boar taint based on the skatole level thresholds $(>0.10 \mu \mathrm{g} / \mathrm{g})$ and the human nose rejection. Different letter $(\mathrm{a}, \mathrm{b})$ next to each bar denotes statistical differences between feeding treatments $(\mathrm{P}=0.06)$ 


\section{Discussion}

This study was intended to evaluate the effects of dietary oat silage supplement and sex on fatty acid profile of perirenal adipose tissue as a carcass lipid proxy. It also assessed some selected boar taint compounds and human nose rejection risk in pork fat from entire males raised under organic production. The results of the fatty acid profile of winter cereal straw and oat silage, two important roughage feed sources for organic pigs in dry areas from south-western Europe, are in agreement with previously published studies from Eastern China (Liu et al., 2020). In addition, the fat content of oat silage is higher than that of straw (Sauvant et al., 2013). It is noteworthy that these two fibre sources differ in their fatty acid composition, as the straw is rich in SFA, mainly palmitic acid (C16:0), whereas oat silage is rich in oleic (C18:1 cis-9) and linoleic (C18: $2 n-6)$ fatty acids. The $\alpha$-linolenic acid (C18:3n-3), the main fatty acid of the $n-3$ family, was found in a smaller proportion in both roughages, but its content was nearly twice in oat silage than in winter cereal straw. Interestingly, the oat silage supplement did not affect the individual SFA and MUFA contents in pork fat, and only reduced the cis-vaccenic fatty acid (C18:1 cis-11) compared to the treatment only provided winter cereal straw, even though these fatty acids differed widely between diets. It has been previously shown that dietary $\mathrm{C} 18: 1$ trans fatty acids, as C18:1 cis-11, which are present in some plant oils, are incorporated into body lipids of pigs and may improve the consistency of their adipose tissue (Fontanillas et al., 1997; Gläser et al., 2002). However, in this study the iodine value of pork fat did not differ across feeding strategies.

In the present work the total SFA content of pork fat was similar in both feeding strategies. This differs from other experiments that included corn silages in the diet of heavy pigs, which found an increase in the SFA fraction of the subcutaneous adipose tissue. This was attributed to an inhibitory effect on the enzyme delta- 9 desaturase that converts the synthesized C18:0 into C18:1 cis-9 (Capraro et al., 2017). In fact, the majority of short and medium chain SFA and MUFA are endogenously synthesized in pig adipocytes, which supports the finding that they were not affected by diet, whereas most of the PUFA are essential and must be supplied by diet (NRC, 2012). The increase of both dietary $n-6$ and $n-3$ in PUFA, by supplementing with oat silage in addition to straw, increased total $n-3$ PUFA and decreased the PUFA $n-6 / n-3$ ratio in perirenal pork fat, although this ratio was still far beyond the recommended ratio of less than 4 (Wood et al., 2004). Although the PUFA content in pork fat is low compared with other feeds as fish meal or fish ingredients, the n-3 fatty acids content and the $n-6 / n-3$ ratio in pigs from oat silage-based production systems may be more beneficial for human nutrition. The higher dietary values of $n-3$ PUFA in oat silage content, linoleic and $\alpha$-linolenic, were reflected in $n-3$ PUFAs contents in the analysed perirenal fat tissue, which was higher than their counterparts on straw (lower n-3 fatty acids), in accordance with Hansen et al. (2006). Sobol et al. (2016) found out that the deposition of n-3 PUFAs in the body depended on the source of fat in the diet and the increase of $n-3$ PUFAs intake increased their deposition in pig adipose tissues. Nevertheless, Nguyen et al. (2003) found, with regression formulas, that $\alpha$-linolenic acid is more efficiently incorporated into intramuscular fat than in adipose tissue. Due to the fact that the concentrate feed was not restricted in the diets (control and silage), the palatability of the straw may be lower than that of the silage, due to a higher content of cell wall fractions (neutral-detergent and aciddetergent fibres) (Sarria and Martens, 2013). Thereby, the cereal straw only acted as a behavioural enrichment material whereas oat silage (even at low doses) could induce carry-over effects on pork fatty acid accretion. The minor PUFA $n-6$, the homo- $\gamma$-linolenic acid (C20:3 n- 6$), n$ - 3 eicosapentaenoic (EPA, C20:5 n-3) and docosahexaenoic (DHA, C22:6n-3), all of them long chain (C20-22) fatty acids of the $n-6$ and $n-3$ series, were higher in perirenal adipose tissue of pigs from oat silage diet, which may be explained by a greater synthesis from their dietary precursors, C18:2 n-6 (LA) and C18:3 n-3 (ALA), respectively (Pauly et al., 2012; Wood et al., 2004) were greater in oat silage than in straw, as long chain PUFA were not detected in the feeds. The greater long-chain PUFA n-3 (EPA and DHA) contents in pork fat from silage fed pigs may be an indicator of more favourable fatty acid composition in their meat (Średnicka-Tober et al., 2016).

Between sexes, total SFA and MUFA content in pork fat were similar but total PUFA and especially $n-6$ PUFA were higher in entire males than gilts, with linoleic acid (C18:2 n-6, LA) being the main n-6 PUFA found in adipose tissue. The present results are in agreement with Grela et al. (2013) that also evaluated the sex effect under organic husbandry. The iodine value, which is used by the packaging industry as an indicator of the quality and firmness of pig carcass fat, would be more favourable in case of gilts than in entire males. Accordingly, Pauly et al. (2012) suggested that the increased content in unsaturated lipids of the adipose tissue in entire males in comparison to gilts and barrows had to be taken into account for maintaining product quality. The higher PUFA levels in oat silage treatment could contribute to undesirable flavours of cooked meat and development of oxidative off-flavours (rancidity) (Gray et al., 1994) in extended pork storage conditions.

The skatole and indole concentration in adipose tissue of entire males was not affected in this study by feeding regime. Results of this work under organic husbandry reported that the greater PUFA in pork fat from oat silage fed pigs was not associated with lower boar taint compounds. This contradicts the results of previous studies, which observed in intensive production conditions, that the entire male pigs with increased PUFA levels and less SFA showed significantly lower skatole and indole levels (Mörlein and Tholen, 2014). Values of skatole and indole below $0.05 \mu \mathrm{g} / \mathrm{g}$ fat are commonly accepted as 
out of the range of detection, even for trained consumers (Font i Furnols et al., 2000). Therefore, the levels of skatole found in the experiment are close to the threshold considered as detectable. In fact, 25 out of 36 animals $(69 \%)$ had values $>0.05 \mu \mathrm{g} / \mathrm{g}$ and 18 out of 36 $(50 \%)>0.10 \mu \mathrm{g} / \mathrm{g}$, and only 11 out 36 animals $(30 \%)$ had values below $0.05 \mu \mathrm{g} / \mathrm{g}$ (not detectable). In the present study, $50 \%$ of the samples fell within the medium and high skatole class groups $(>0.10 \mu \mathrm{g} / \mathrm{g})$. This outcome is higher than the normal prevalence of boar taint in intensive pig Spanish production ( $80 \mathrm{~kg}$ carcasses), which only accounted for $11 \%$ of the pork fat within this risk skatole threshold (Borrisser-Pairó et al., 2016), which may be linked to a heavier slaughter weight in this experiment.

Apparently, supplementation with oat silage did not alter the concentration of skatole or indole, however, according to human nose technique there was a tendency to increase the detection of sexual odour $(21.1 \%$ vs. $47.1 \%$ of sexual odour samples, $\mathrm{P}=0.06$ ). It should be considered that the human nose scoring does not allow differentiating between an unpleasant odour related to skatole alone, androstenone alone or both, but the risk of boar taint based on this method of discrimination could affect one or both of these two molecules (Parois et al., 2018). Mathur et al. (2012) described the correlations of human nose scoring with androstenone ranged from 0.22 to 0.52 , while those with skatole ranged from 0.31 to 0.89 , suggesting that skatole is a better predictor of boar taint, which would be detected by approximately $16-20 \%$ of the Spanish consumers (Panella-Riera et al., 2016), while certain percentage of people are completely anosmic or only partially detect androstenone.

The inclusion of both straw and oat silage (dietary fibres) may affect the skatole production across the digestive tract since diets with high content of fermentable carbohydrates have been shown to reduce the level of cholesterol in serum (Hansen et al., 2008) and the production of skatole in backfat (Jensen and Hansen, 2006). Whereas in this experiment it was proved that the oat silage supplement reduced the cholesterol content in adipose tissue (Argemí-Armengol et al., 2020), the levels of skatole were not reduced in fat tissue. In this work, the degradation of non-starch polysaccharides (NSP) of roughages in the large intestine of pigs was not determined, but it depends on the degree of lignification, solubility and structure of the polysaccharides (Bach Knudsen, 2001). However, although the skatole content in perirenal adipose tissue was similar, a blind trained panellist discriminated between roughage feeds by human nose. The blind trained panellist also showed a good agreement when rejecting pork fat with the medium and high skatole result analysis (67\% of agreement between rankings). This would highlight that additional compounds as aldehydes and short chain fatty acids play a significant role in the development of off-flavours in pig backfat samples classified with boar taint (Rius et al., 2005).

\section{Conclusions}

It can be concluded that there was no significant effect of silage or sex on total SFA and MUFA in pork fat. However, the higher supply of PUFA in the organically fed pigs with oat silage was reflected in the perirenal adipose tissue, increasing the content of total n-3 PUFA (mainly $\alpha$-linolenic) and decreasing the PUFA n- $6 / n-3$ ratio. From a health perspective, these results confirm the potential of pork fat to supply valuable n-3 PUFA to the human diet. Fat quality from entire males had a greater PUFA/SFA ratio than that of gilts. Future studies to disentangle the individual variability at similar slaughter body-weights, and its relation with feeding strategies, are needed to produce entire males without the problem of taint detection.

\section{Acknowledgments}

The authors are indebted to the owners from 'Granja Casat' farm (Sarroca Bellera, Catalonia, Spain) for caring for the animals, and 'Escorxador del Moianès' (Moià, Catalonia, Spain) for kindly supplying pork samples. This research was funded by the Technology Transfer operation of the Rural Development Program of Catalonia 2014-2020 (Government of Catalonia and the European Regional Development Funds, Grant code 01.02.01).

\section{Financial support}

This research was funded by the Technology Transfer operation of the Rural Development Program of Catalonia 2014-2020 (Government of Catalonia and the European Regional Development Funds, Grant code 01.02.01).

\section{Declaration of competing interest}

The authors declare no competing financial interest. The funders had no role in the design of the study; in the collection, analyses, or interpretation of data; in the writing of the manuscript, or in the decision to publish the results.

\section{References}

Aaslyng M.D., Støier S., Lund B.W., Nielsen D.B. (2019). Slaughtering of entire male pigs seen from the slaughterhouse perspective. IOP Conference Series: Earth Environ. Sci., 333: 012003.

Álvarez-Rodríguez J., Villalba D., Cubiló D., Babot D., Tor M. (2016). Organic practices and gender are effective strategies to provide healthy pork loin. J. Integr. Agricult., 15: 608-617.

AOAC (2000). Official methods of analysis. Association of Official Analytical Chemists. 17th ed., Arlington, VA.

AOCS (1998). Official methods and recommended practices of the American Oil Chemists' Society (AOCS). 5th ed OACS Champaign IL.

Argemí-Armengol I., Villalba D., Tor M., Bertolín J.R., Latorre M.A., Álvarez-Rodríguez J. (2020). Effects of dietary roughage on organic pig performance behaviour and antioxidants accretion in perirenal adipose tissue. Livest. Sci., 241: 104255.

Bach Knudsen K.E. (2001). The nutritional significance of 'dietary fibre' analysis. Anim. Feed Sci. Technol., 90: 3-20. 
Bonneau M., Chevillon P. (2012). Acceptability of entire male pork with various levels of androstenone and skatole by consumers according to their sensitivity to androstenone. Meat Sci., 90: 330337.

Bonneau M., Kempster A.J., Claus R., Claudi-Magnussen C., Diestre A., Tornberg E., Walstra P., Chevillon P., Weiler U., Cook G.L. (2000). An international study on the importance of androstenone and skatole for boar taint: I Presentation of the programme and measurement of boar taint compounds with different analytical procedures. Meat Sci., 54: 251-259.

Borrisser-Pairó F., Panella-Riera N., Zammerini D., Olivares A., Garrido M.D., Martínez B., Gil M., García-Regueiro J.A., Oliver M.A. (2016). Prevalence of boar taint in commercial pigs from Spanish farms. Meat Sci., 111: 177-182.

Capraro D., Buccioni A., Piasentier E., Spanghero M. (2017). Feeding finishing heavy pigs with corn silages: effects on backfat fatty acid composition and ham weight losses during seasoning. It. J. Anim. Sci., 16: 588-592.

Daza A., Olivares A., Latorre M.A., Rey A.I., Callejo A., López-Bote C.J. (2017). Fatty acid composition of different adipose tissues in heavy pigs. It. J. Anim. Sci., 29: 657-666.

Font i Furnols M., Guerrero L., Serra X., Rius M.À., Oliver M.À. (2000). Sensory characterization of boar taint in entire male pigs. J. Sensory Stud., 15: 393-409.

Font i Furnols M., Gispert M., Diestre A., Oliver M.A. (2003). Acceptability of boar meat by consumers depending on their age gender culinary habits and sensitivity and appreciation of androstenone odour. Meat Sci., 64: 433-440.

Fontanillas R., Barroeta A., Baucells M.D., Codony R. (1997). Effect of feeding highly cis-monounsaturated trans or $\mathrm{n}-3$ fats on lipid composition of muscle and adipose tissue of pigs. J. Agricult. Food Chem., 45: 3070-3075.

García-Regueiro J.A., Rius M.A. (1998). Rapid determination of skatole and indole in pig back fat by normal-phase liquid chromatography. J. Chromat. A, 809: 246-251.

Gläser K., Wenk C., Scheeder M.R.L. (2002). Effects of feeding pigs increasing levels of C 18:1 Trans fatty acids on fatty acid composition of backfat and intramuscular fat as well as backfat firmness. Arch. Tierernahr., 56: 117-130.

Gray J.I., Pearson A.M. (1994). Lipid-derived off-flavours in meatformation and inhibition. In: Flavor of meat and meat products, Shahidi F. (ed.). Springer, Boston, MA.

Grela E.R., Kowalczuk-Vasilev E., Klebaniuk R. (2013). Performance pork quality and fatty acid composition of entire males surgically castrated or immunocastrated males and female pigs reared under organic system. Pol. J. Vet. Sci., 16: 107-114.

Hansen L.L., Claudi-Magnussen C., Jensen S.K., Andersen H.J. (2006). Effect of organic pig production systems on performance and meat quality. Meat Sci., 74: 605-615.

Hansen L.L., Stolzenbach S., Jensen J.A., Henckel P., Hansen-Møller J., Syriopoulos K., Byrne D.V. (2008). Effect of feeding fermentable fibre-rich feedstuffs on meat quality with emphasis on chemical and sensory boar taint in entire male and female pigs. Meat Sci., 80: 1165-1173.

Hathwar S.C., Rai A.K., Modi V.K., Narayan B. (2012). Characteristics and consumer acceptance of healthier meat and meat product formulations - a review. J. Food Sci. Technol., 49: 653-664.

INRA (2008). Equations and coefficients. Version 13. Inra Afz Ajinomoto Eurolysine Sas, pp.1-20. http://www.evapig.com

ITAB (2014). Alimentation des porcs en agriculture biologique, Roinsard A., Catherine C., Maupertuis F., Alibert L., Ferchaud S., Uzereau A., Carrière J., Bordes A. (eds). ITAB - Institut Technique de l'Agriculture Biologique. Cah. Tech., pp. 1-40.

Jensen M.T., Hansen L.L. (2006). Feeding with chicory roots reduces the amount of odorous compounds in colon and rectal contents of pigs. Animal Sci., 82: 369-376.

Liu Q.H., Wu J.X., Dong Z.H., Wang S.R., Shao T. (2020). Effects of overnight wilting and additives on the fatty acid profile $\alpha$-tocopherol and $\beta$-carotene of whole plant oat silages. Anim. Feed Sci. Technol., 260: 114370.
Mathur P.K., Ten Napel J., Bloemhof S., Heres L., Knol E.F., Mulder H.A. (2012). A human nose scoring system for boar taint and its relationship with androstenone and skatole. Meat Sci., 91: 414-422.

Mörlein D., Tholen E. (2014). Fatty acid composition of subcutaneous adipose tissue from entire male pigs with extremely divergent levels of boar taint compounds - An exploratory study. Meat Sci., 99: 1-7.

Nguyen L.Q., Nuijens M.C.G.A., Everts H., Salden N., Beynen A.C. (2003). Mathematical relationships between the intake of $n-6$ and $\mathrm{n}-3$ polyunsaturated fatty acids and their contents in adipose tissue of growing pigs. Meat Sci., 65: 1399-1406.

NRC (2012). Nutrient requirements of swine. National Research Council. National Academies Press. 11th ed., 215 pp.

Panella-Riera N., Blanch M., Kallas Z., Chevillon P., Garavaldi A., Gil M., Gil J.M., Font-i-Furnols M., Oliver M.A. (2016). Consumers' segmentation based on the acceptability of meat from entire male pigs with different boar taint levels in four European countries: France, Italy, Spain, and United Kingdom. Meat Sci., 114: 137-145.

Parois S., Bonneau M., Chevillon P., Larzul C., Quiniou N., Robic A., Prunier A. (2018). Odeurs indésirables de la viande de porcs mâles non castrés : problèmes et solutions potentielles. INRA Productions Animales, 31: 23-36.

Pauly C., Luginbühl W., Ampuero S., Bee G. (2012). Expected effects on carcass and pork quality when surgical castration is omitted Results of a meta-analysis study. Meat Sci., 92: 858-862.

Raes K., De Smet S., Demeyer D. (2004). Effect of dietary fatty acids on incorporation of long chain polyunsaturated fatty acids and conjugated linoleic acid in lamb beef and pork meat: A review. Anim. Feed Sci. Technol., 113: 199-221.

Rey A.I., Daza A., López-Carrasco C., López-Bote C.J. (2006). Feeding Iberian pigs with acorns and grass in either free-range or confinement affects the carcass characteristics and fatty acids and tocopherols accumulation in Longissimus dorsi muscle and backfat. Meat Sci., 73: 66-74.

Rius M.A., Hortós M., García-Regueiro J.A. (2005). Influence of volatile compounds on the development of off-flavours in pig back fat samples classified with boar taint by a test panel. Meat Sci., 71: 595-602.

Sarria P.I.B., Martens S.D. (2013). The voluntary intake in growing pigs of four ensiled forage species. Agricult. Food Sci., 22: 201-216.

Sauvant D., Tran G., Heuzé V., Bastianelli D., Archimède H. (2013). Feedipedia: une encyclopédie mondiale des ressources alimentaires pour les animaux d'élevage. https://www.feedipedia.org

Sobol M., Raj S., Skiba G. (2016). Effect of fat content in primal cuts of pigs fed diet enriched in n-3 polyunsaturated fatty acids on health-promoting properties of pork. J. Anim. Feed Sci., 25: 20-28.

Średnicka-Tober D., Barański M., Seal C., Sanderson R., Benbrook C., Steinshamn H., Gromadzka-Ostrowska J., Rembiałkowska E., Skwarło-Sońta K., Eyre M., Cozzi G., Larsen M.K., Jordon T., Niggli U., Sakowski T., Calder P.C., Burdge G.C., Sotiraki S., Stefanakis A., Yolcu H., Stergiadis S., Chatzidimitriou E., Butler G., Stewart G., Leifert C. (2016). Composition differences between organic and conventional meat: a systematic literature review and meta-analysis. Brit. J. Nutr., 23: 1-18.

Sukhija P.S., Palmquist D.L. (1988). Rapid method for determination of total fatty acid content and composition of feedstuffs and feces. J. Agricult. Food Chem., 36: 1202-1206.

Thomsen R., Bonde M., Kongsted A.G., Rousing T. (2012). Welfare of entire males and females in organic pig production when reared in single-sex groups. Livest. Sci., 149: 118-127.

Wallenbeck A., Rundgren M., Presto M. (2014). Inclusion of grass/ clover silage in diets to growing/finishing pigs - Influence on performance and carcass quality. Acta Agricult. Scand., A-Anim. Sci., 64: 145-153.

Wood J.D., Richardson R.I., Nute G.R., Fisher A.V., Campo M.M., Kasapidou E., Sheard P.R., Enser M. (2004). Effects of fatty acids on meat quality: a review. Meat Sci., 66: 21-32. 
Yagoubi Y., Joy M., Ripoll G., Mahouachi M., Bertolín J.R., Atti N. (2018). Rosemary distillation residues reduce lipid oxidation increase alpha-tocopherol content and improve fatty acid profile of lamb meat. Meat Sci., 136: 23-29.

Zamaratskaia G., Squires E.J. (2009). Biochemical, nutritional and genetic effects on boar taint in entire male pigs. Animal, 3: $1508-1521$

Received: 15 VI 2021

Accepted: 13 X 2021 